Article

\title{
Palladium(II)-Acetylacetonato Complexes with Mesoionic Carbenes: Synthesis, Structures and Their Application in the Suzuki-Miyaura Cross Coupling Reaction
}

\author{
Lara Hettmanczyk, Bianca Schmid, Stephan Hohloch and Biprajit Sarkar* \\ Institut für Chemie und Biochemie, Anorganische Chemie, Freie Universität Berlin, Fabeckstraße 34-36, \\ Berlin D-14195, Germany; Lara.Hettmanczyk@fu-berlin.de (L.H.); bianca.schmid@chem.tu-berlin.de (B.S.); \\ Stephan.Hohloch@web.de (S.H.) \\ * Correspondence: biprajit.sarkar@fu-berlin.de; Tel.: +49-30-838-50919; Fax: +49-30-838-53310 \\ Academic Editors: James Crowley and Derek J. McPhee \\ Received: 20 September 2016; Accepted: 12 November 2016; Published: 17 November 2016
}

\begin{abstract}
A series of novel palladium(II) acetylacetonato complexes bearing mesoionic carbenes (MICs) have been synthesized and characterized. The synthesis of the complexes of type (MIC)Pd(acac)I (MIC = 1-mesityl-3-methyl-4-phenyl-1,2,3-triazol-5-ylidene (1), 1,4-(2,4,6-methyl)-phenyl-3-methyl1,2,3-triazol-5-ylidene (2), 1,4-(2,6-diisopropyl)-phenyl-3-methyl-1,2,3-triazol-5-ylidene (3); acac = acetylacetonato) via direct metalation starting from the corresponding triazolium iodides and palladium(II) acetylacetonate is described herein. All complexes were characterized by ${ }^{1} \mathrm{H}$ - and ${ }^{13} \mathrm{C}-\mathrm{NMR}$ spectroscopy and high resolution mass spectrometry. Additionally, two of the complexes were characterized by single crystal X-ray crystallography confirming a square-planar coordination geometry of the palladium(II) center. A delocalized bonding situation was observed within the triazolylidene rings as well as for the acac ligand respectively. Complex 2 was found to be an efficient pre-catalyst for the Suzuki-Miyaura cross coupling reaction between aryl-bromides or -chlorides with phenylboronic acid.
\end{abstract}

Keywords: mesoionic carbenes; triazolylidenes; palladium; Suzuki-Miyaura cross coupling; click chemistry; abnormal carbenes

\section{Introduction}

$\mathrm{N}$-heterocyclic carbenes (NHCs) are a very attractive class of compounds. Because of their easy accessibility and their high complex stability, these ligands have been used extensively in organometallic chemistry in the last decades [1-6]. They are mainly applicable in homogeneous catalysis $[7,8]$ but also in other fields of chemistry such as material science $[9,10]$, bioorganometallic chemistry [10-12] or metallosupramolecular chemistry [13-15]. A special kind of NHCs are mesoionic carbene (MIC), which have received high popularity in recent years. Apart from imidazol-5-ylidenes, 1,2,3-triazol-5-ylidenes are the most noted MICs found in the literature [16-22]. Their precursors, the 1,2,3-triazoles, are easily accessible via the copper(I) catalyzed azide-alkyne cycloaddition (CuAAC) reaction [23-27]; subsequent alkylation results in the corresponding 1,2,3-triazolium salts, which can be converted into mesoionic carbenes [6,22,28]. Metal complexes of 1,2,3-triazol-5-ylidenes are used as catalysts in a variety of catalytic transformations [16-21]. For example, copper(I) complexes have been found to be potent catalysts for the "click" reaction [29-34], while cyclization reactions can be performed using gold(I) 1,2,3-triazol-5-ylidene complexes as catalysts [14,28,35-41]. Iridium(III) complexes were shown to be efficient catalysts in water oxidation reactions $[9,42-45]$ as well as other oxidation reactions and transfer hydrogenations [46-51], which are also catalyzed by ruthenium(II) 
and osmium(II) complexes [46,47,49,50,52-58]. Furthermore, 1,2,3-triazol-5-ylidenes and their metal complexes have also been investigated for their photochemical [59-64] and redox properties [60,65].

Especially palladium(II) 1,2,3-triazol-5-ylidene complexes obtained a lot of attention since the discovery of 1,2,3-triazol-5-ylidene complexes [22]. Various types of palladium(II) complexes show diversities in the coordination fashion and have different additional ligands (Figure 1) [22,38,65-82]. Almost all palladium(II) complexes were used as catalysts in a variety of cross coupling reactions. Mainly, they are used as pre-catalysts in reactions like the Suzuki-Miyaura cross coupling reaction [68-75,80-83] or $\alpha$-arylation and $\alpha$-methylation reactions $[38,75,80]$.

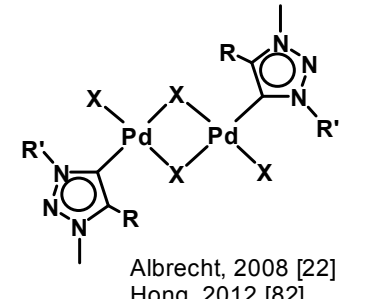
Hong, 2012 [82]

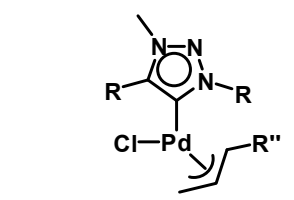

Fukuzawa, 2012 [71] Mendoza-Espinosa, 2015 [38]

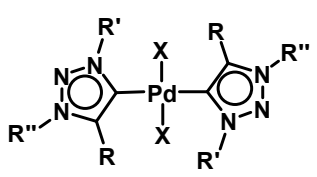

Sakararaman, 2009 [69] Fukuzawa, 2010 [68] Sarkar, 2013 [72]

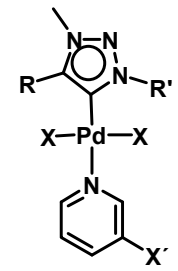

Albrecht, 2012 [70] Crudden, 2012 [67] Hong 2012 [82]

Sarkar, 2015 [72]

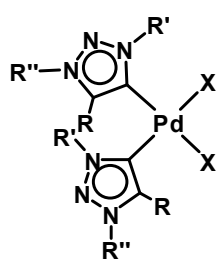

Sankararaman, 2009 [69]

Albrecht, 2011 [66]

Sarkar, 2013 [72]

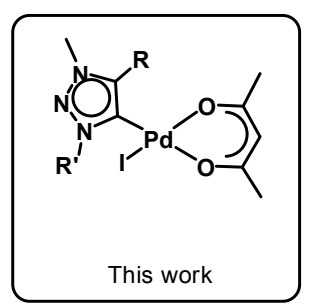

Figure 1. Overview of selected palladium(II) complexes with 1,2,3-triazol-5-ylidene ligands.

We have been interested in the development of a novel coordination motif of palladium(II) 1,2,3-triazol-5-ylidenes complexes, in which $\kappa^{2}$-acetylacetonate is coordinated as additional chelating ligand to the palladium(II) center. For normal $N$-heterocyclic carbenes (NHC), these kind of palladium(II) complexes, but with chlorido instead of iodido as ligand, were first reported in 2005 [84]. These NHC complexes showed high catalytic activity in the Buchwald-Hartwig amination and in the arylation of $\alpha$-ketones $[85,86]$.

Herein we report on the synthesis of a series of novel palladium(II) acetylacetonato complexes bearing mesoionic carbenes. The complexes have been characterized by ${ }^{1} \mathrm{H}-$ and ${ }^{13} \mathrm{C}-\mathrm{NMR}$ spectroscopy, mass spectrometry and single crystal X-ray crystallography. Their catalytic activity in the Suzuki-Miyaura cross coupling reaction are presented as well.

\section{Results and Discussion}

\subsection{Synthesis and Characterization of the Palladium(II) Complexes}

The triazolium salts [HL1]I [70,87], [HL2]I [68] and [HL3]I [32] were synthesized according to procedures reported in the literature. The complexes 1-3 were synthesized in a one-pot reaction starting from the corresponding triazolium salts via direct metalation by use of $\left[\mathrm{Pd}(\mathrm{acac})_{2}\right]$ under inert conditions (Scheme 1). The route used here is similar as for the preparation of related $\mathrm{nNHC}$ complexes [85], but for the triazolylidene complexes the iodides of the triazolium salts were used because of synthetic ease. One of the acac ligands on $\left[\mathrm{Pd}(\mathrm{acac})_{2}\right]$ acts as an internal base for the deprotonation of the triazolium salts. The coordinated iodides on the palladium centers originate from the corresponding triazolium salts (Scheme 1). The identity and purity of the compounds were 
unambiguously proven by mass spectrometry, ${ }^{1} \mathrm{H}$ - and ${ }^{13} \mathrm{C}-\mathrm{NMR}$ spectroscopy. All complexes were isolated as yellow solids after precipitation or as yellow crystalline solids after recrystallization from a mixture of dichloromethane and hexane. In contrast to the achieved moderate to good yields of these MIC complexes, the yields obtained for the nNHC complexes have been nearly quantitative [85], even under aerobic conditions [86]. The reason for this might be the higher acidity of the imidazolium-2H [88-90] in comparison with the acidity of the triazolium-5H [19,91]. While the solubility of complexes 1-3 is very high in THF, diethyl ether, toluene or chlorinated solvents, the complexes were only moderately to sparingly soluble in hexane or pentane.
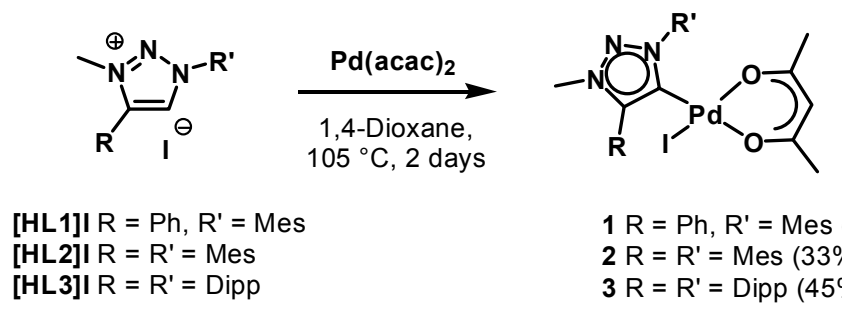

$\mathrm{Ph}=$ Phenyl, Mes = Mesityl, Dipp = 2,6-Diisopropylphenyl

Scheme 1. Synthesis of the palladium(II) MIC complexes.

The first indication for the formation of the palladium(II) MIC complexes in solution was the disappearance of the triazolium- $5 \mathrm{H}$ in the ${ }^{1} \mathrm{H}$-NMR spectra and the appearance of the single proton of the bound acac ligand at 5.14, 5.12 and $5.13 \mathrm{ppm}$ for $\mathbf{1}, \mathbf{2}$ and $\mathbf{3}$ respectively. Further proof was given by ${ }^{13} \mathrm{C}$-NMR spectroscopy based on the signals of the carbene carbons at 151.1 and $150.2 \mathrm{ppm}$ for 2 and 3 respectively. Unfortunately, the signal corresponding to the carbene carbon for $\mathbf{1}$ was not resolved in its ${ }^{13} \mathrm{C}-\mathrm{NMR}$ spectrum. Two signals of the quaternary carbons of the bound acac ligand was observable for each complex in the range of 183-187 ppm (see Figures S1-S3). For the methyl-group of the acac ligand two separate signals could be observed in the ${ }^{1} \mathrm{H}-\mathrm{NMR}$ as well as in the ${ }^{13} \mathrm{C}-\mathrm{NMR}$ spectra. Additional characterization of the complexes by ESI-MS showed molecular peaks corresponding to the molecular mass with loss of the iodide (see ESI).

\subsection{Structural Characterization}

The molecular structures of palladium(II) complexes $\mathbf{1}$ and $\mathbf{3}$ in crystal could be confirmed by single crystal X-ray crystallography (Figure 2). Single crystals were grown by slow diffusion of hexane onto a concentrated solution in dichloromethane. Crystallographic details for these complexes are given in Table S1. Important bond length and angles are depicted in Table 1.

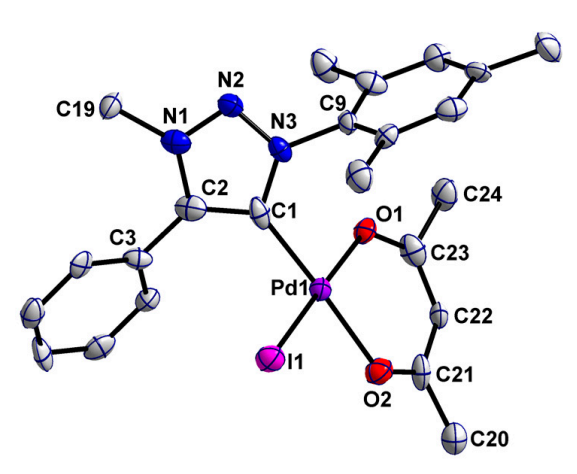

(a)

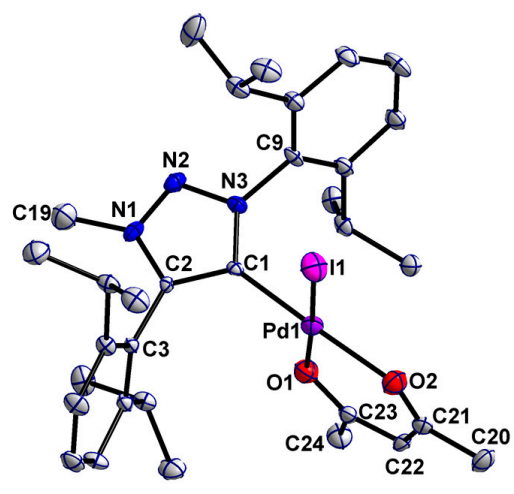

(b)

Figure 2. Perspective view of complexes 1 (a) and 3 (b). Ellipsoids are drawn at the $50 \%$ probability level. Hydrogen atoms have been omitted for clarity. 
Table 1. Selected bond length $(\AA)$ and angles $\left(^{\circ}\right)$.

\begin{tabular}{|c|c|c|}
\hline Atoms & 1 & 3 \\
\hline $\mathrm{C} 1-\mathrm{C} 2$ & $1.37(2)$ & $1.387(6)$ \\
\hline C1-N3 & $1.36(1)$ & $1.376(6)$ \\
\hline C2-N1 & $1.37(1)$ & $1.354(6)$ \\
\hline N1-N2 & $1.32(1)$ & $1.304(6)$ \\
\hline N2-N3 & $1.32(1)$ & $1.351(6)$ \\
\hline $\mathrm{Pd} 1-\mathrm{C} 1$ & $1.98(1)$ & $1.957(5)$ \\
\hline Pd1-I1 & $2.561(1)$ & $2.560(1)$ \\
\hline Pd1-O1 & $2.027(7)$ & $2.054(4)$ \\
\hline $\mathrm{Pd} 1-\mathrm{O} 2$ & $2.060(7)$ & $2.046(4)$ \\
\hline $\mathrm{O} 1-\mathrm{C} 23$ & $1.27(1)$ & $1.264(6)$ \\
\hline $\mathrm{O} 2-\mathrm{C} 21$ & $1.27(1)$ & $1.281(7)$ \\
\hline $\mathrm{C} 23-\mathrm{C} 22$ & $1.39(2)$ & $1.398(8)$ \\
\hline C21-C22 & $1.42(2)$ & $1.379(8)$ \\
\hline C1-C2-N1 & $106(1)$ & $107.5(4)$ \\
\hline C2-C1-N3 & $103(1)$ & $103.3(4)$ \\
\hline C1-N3-N2 & $114.9(8)$ & $112.0(4)$ \\
\hline C2-N1-N2 & $112.5(9)$ & $111.9(4)$ \\
\hline N1-N2-N3 & $103.1(8)$ & $105.4(4)$ \\
\hline C23-C22-C21 & $127(1)$ & $127.0(5)$ \\
\hline $\mathrm{O} 1-\mathrm{C} 23-\mathrm{C} 22$ & $127(1)$ & $126.8(5)$ \\
\hline $\mathrm{O} 2-\mathrm{C} 21-\mathrm{C} 22$ & $125(1)$ & $127.0(5)$ \\
\hline C1-Pd1-I1 & $90.4(3)$ & $88.9(1)$ \\
\hline C1-Pd1-O1 & $89.1(4)$ & $88.7(2)$ \\
\hline C1-Pd1-O2 & $177.1(4)$ & $178.4(2)$ \\
\hline I1-Pd1-O1 & $175.3(2)$ & $177.4(1)$ \\
\hline I1-Pd1-O2 & $88.8(2)$ & $90.5(1)$ \\
\hline O1-Pd1-O2 & $91.9(3)$ & $91.9(2)$ \\
\hline $\operatorname{trz}-\operatorname{Ar}\left(\mathrm{C}_{\mathrm{trz}}\right)^{*}$ & 46.7 & 86.0 \\
\hline $\operatorname{trz}-\operatorname{Ar}\left(\mathrm{N}_{\mathrm{trz}}\right) *$ & 47.5 & 71.1 \\
\hline trz-acac * & 57.1 & 82.7 \\
\hline
\end{tabular}

* Planes measured with the program Diamond 4.0.2; trz = triazolylidene.

Complex 1 crystallized as yellow needles in the orthorhombic space group Pcba, while complex 3 crystallized as yellow plates in the monoclinic space group $\mathrm{P} 2{ }_{1} / n$ (see Table $\mathrm{S} 1$ ). The $\mathrm{C}-\mathrm{C}, \mathrm{C}-\mathrm{N}$ and $\mathrm{N}-\mathrm{N}$ bond lengths and the corresponding angles within the five-membered triazolylidene rings indicate a delocalized bonding situation in those rings for both complexes (Table 1). The aryl-substituents are twisted with respect to the triazolylidene ring. In complex 1 the dihedral angles between the aryl-substituents and the triazolylidene ring are $46.7^{\circ}$ and $47.5^{\circ}$. The Dipp-substituents in complex 3 are almost perpendicular to the triazolyldiene rings with dihedral angles of $86.0^{\circ}$ and $71.1^{\circ}$. The large twists observed in the aforementioned case is likely due to the higher steric demand of the Dipp substituents (Table 1). Within the acac ligand, the bond length and angles are also indicative of a delocalized bonding situation.

Both palladium(II) MIC complexes display an almost square-planar coordination geometry, in which the angles between palladium and the different ligands are in between $88.7(2)^{\circ}$ and $91.9(3)^{\circ}$. The square-planar geometry is typical for palladium(II) centers with a $\mathrm{d}^{8}$ electronic configuration. The related nNHC complex showed a slightly higher deviation from the perfect square-planar geometry [84]. In complex 1 the triazolylidene ring is twisted about $57.1^{\circ}$ with respect to the acac-Pd plane, while in complex 3 the triazolylidene ring is rotated about $82.7^{\circ}$ resulting from the higher steric demand of the Dipp substituents (Table 1).

The distances between the palladium atoms and the carbene carbon atoms are almost similar in both complexes with 1.98 (1) $\AA$ and 1.957 (5) $\AA$ respectively, which is in accordance with other palladium(II) triazolylidene complexes [65,75,80,92]. The Pd-C bond length of 1.969 (2) $\AA$ for the related nNHC complex lies in between the Pd-C distances of the MIC complexes reported here [84]. 
The Pd-I distances of 2.561 (1) $\AA$ and 2.560 (1) $\AA$ are a bit lower compared to Pd-I bond distances in other palladium(II) MIC complexes [65,75,80,92]. While the acac ligand in $\mathbf{1}$ is unsymmetrically bound to the Pd center (2.027 (7) $\AA$ and 2.060 (7) $\AA$ ) in 3 the bonding situation was found to be more symmetric with Pd-O1 and Pd-O2 being 2.054 (4) $\AA$ and 2.046 (4) $\AA$ respectively. For the related nNHC complex the Pd-O bond length are shorter with 2.044 (1) $\AA$ and 2.036 (2) $\AA$ compared to the MIC complexes [84].

\subsection{Catalysis}

Palladium(II) NHC complexes in general are known to be effective catalysts in various transformations and therefore they play a central role in organic chemistry $[3,7,93,94]$. Different bonds such as $\mathrm{C}-\mathrm{X}(\mathrm{X}=$ halide) can be activated and new $\mathrm{C}-\mathrm{C}$ or $\mathrm{C}-\mathrm{N}$ bonds can be built. Also, many examples for catalytically active palladium(II) MIC complexes in cross coupling reactions are known in the literature. The main application was reported in Suzuki-Miyaura coupling reactions $[68-75,80,81,83]$, Mizoroki-Heck reactions [67] or Hiyama coupling reactions [77,78]. Other reactions like $\alpha$-arylation or $\alpha$-methylation $[38,75,80]$ and the Buchwald-Hartwig reaction [79] were presented as well.

To gain an insight into the catalytic activity of our novel palladium(II) MIC complexes we have chosen the Suzuki-Miyaura cross coupling and the Buchwald-Hartwig amination reactions as examples and complexes $\mathbf{2}$ and $\mathbf{3}$ as pre-catalysts. Both complexes show good to excellent activities in the Suzuki-Miyaura cross-coupling reaction between aryl bromides and chlorides with phenylboronic acid (Scheme 2).
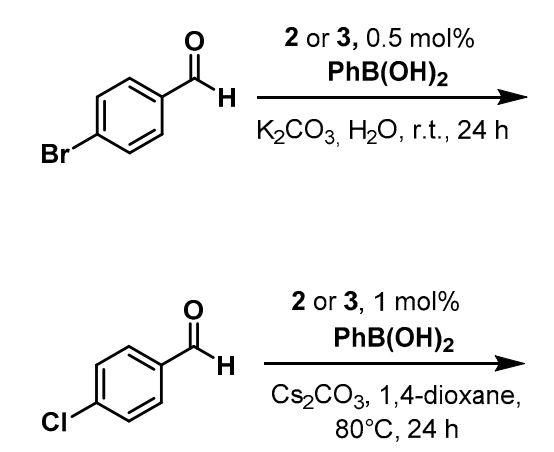

$$
\mathrm{c}
$$

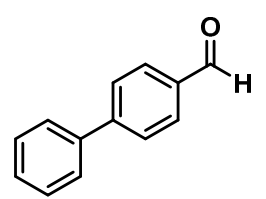

2: $82 \%$

3: $78 \%$<smiles>O=Cc1ccc(-c2ccccc2)cc1</smiles>

2: $78 \%$

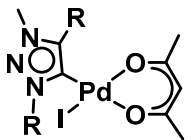

2: $R=$ Mes 3: $R=$ Dipp

Scheme 2. Palladium(II) mesoionic carbene (MIC) complexes 2 and 3 as pre-catalysts in the SuzukiMiyaura cross coupling reaction.

For 4-bromobenzaldehyde, the reaction could be performed in the environment-friendly solvent water at room temperature under air, using potassium carbonate as base. With a catalyst loading of only $0.5 \mathrm{~mol} \%$ of 2 a conversion of $82 \%$ could be obtained within $24 \mathrm{~h}$. For complex 3 , the conversion was fairly similar at $78 \%$. In the case of 4-chlororbenzaldehyde, which tends to be less easy to activate, the reaction conditions had to be changed. Therefore, we used 1,4-dioxane as the solvent under an $\mathrm{Ar}$ atmosphere, cesium carbonate as a base and the reaction temperature was increased to $80^{\circ}$. Applying these conditions, we were able to achieve a conversion of $78 \%$ within $24 \mathrm{~h}$ with catalyst loadings of $1 \mathrm{~mol} \%$ of 2 . For 3 , the conversion was $56 \%$ under the same conditions. Additionally, we investigated the Buchwald-Hartwig amination reaction with both 2 and 3 as pre-catalysts under microwave irradiation conditions. This was necessary as the Buchwald-Hartwig amination is intrinsically a more difficult reaction to perform in comparison to the Suzuki-Miyaura cross-coupling reaction. Unfortunately, with complex 2, no conversion was observed under the used conditions. With complex 3, however, we were able to observe $30 \%$ conversions to product by using $4.4 \%$ catalyst loading under only $15 \mathrm{~min}$ of microwave irradiation (Scheme 3). The investigation of these two classes of catalytic reactions shows that the substituents on the triazolylidene ligands do have a direct or an indirect 
influence on the catalytic activities of the resulting palladium complexes. In the Suzuki-Miyaura cross-coupling reaction, the activity of the complexes presented here seems to be better than those of the corresponding PEPPSI complexes containing triazolylidene ligands, in which case a catalyst loading of $2.5 \mathrm{~mol} \%$ (in comparison to $0.5 \mathrm{~mol} \%$ ) was necessary with similar substrates [80]. These results indicate a positive effect of the use of the acac containing complexes for these kinds of catalysis.

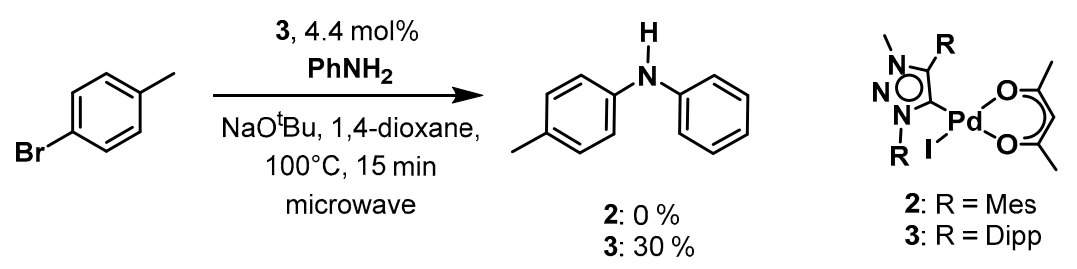

Scheme 3. Palladium(II) MIC complex 3 as pre-catalyst in the Buchwald-Hartwig amination.

\section{Materials and Methods}

\subsection{General Procedures, Materials and Instrumentations}

The triazolium salts [HL1]I [70,87], [HL2]I [68] and [HL3]I [32] were prepared as described previously in the literature. Commercially available chemicals were used as purchased, unless otherwise noted. The solvents used for synthesis and catalysis were dried and distilled under inert gas and degassed by common techniques prior to use, unless otherwise noticed. ${ }^{1} \mathrm{H}$ - and ${ }^{13} \mathrm{C}-\mathrm{NMR}$ spectra were recorded on a Jeol ECS 400 or Jeol ECZ 400R spectrometer (Joel, Munich, Germany) using the chemical shift of the solvent as an internal standard. Multiplets are reported as follows: singlet (s), duplet (d), triplet ( $\mathrm{t}$ ) quartet (q), quintet (quint), and combinations thereof. Mass spectrometry was performed on an Agilent 6210 ESI-TOF (Agilent, Walbronn, Germany).

\subsection{X-ray Crystallography}

X-Ray data were collected on a Bruker Smart AXS diffractometer (Bruker, Karlsruhe, Germany). Data were collected at 140(2) K (see Table S1) using graphite-monochromated Mo K $\alpha$ radiation $\left(\lambda_{\alpha}=0.71073 \AA\right)$. The strategy for the data collection was evaluated by using the Smart software (Bruker, AXS Inc., Madison, WI, USA). The data were collected by the standard ' $\omega$ scan techniques' and were scaled and reduced using Saint+ and SADABS software. The structures were solved by direct methods using SHELXS-97 or SHELXS_2014/7 and refined by full matrix least-squares, refining on $\mathrm{F}^{2}$. Non-hydrogen atoms were refined anisotropically [95-101]. If it is noted, bond length and angles were measured with Diamond Crystal Version 4.0.2 (Crystal Impact GbR, Bonn, Germany) and Molecular Structure Visualization Version 3.1 (Crystal Impact GbR). CCDC 965893 and 1015507 contains the supplementary crystallographic data for this paper. These data can be obtained free of charge via http:/ / www.ccdc.cam.ac.uk/conts/retrieving.html (or from the CCDC, 12 Union Road, Cambridge CB2 1EZ, UK; Fax: +44 1223 336033; E-mail: deposit@ccdc.cam.ac.uk)

\subsection{Synthesis}

\subsubsection{General Procedure for the Preparation of the Palladium(II) 1,2,3-Triazolylidene Complexes 1-3}

The corresponding triazolium salt [HL1]I, [HL2]I or [HL3]I $(0.2 \mathrm{mmol}, 1$ eq. $)$ and palladium(II) acetylacetonate $(60.9 \mathrm{mg}, 0.2 \mathrm{mmol}, 1$ eq.) were dissolved in absolute 1,4-dioxane ( $3 \mathrm{~mL}$ ) and stirred for $48 \mathrm{~h}$ at $105^{\circ} \mathrm{C}$. The reaction mixture was filtered over Celite and volatiles were removed under vacuum. The residue was re-resolved in dichloromethane $(2 \mathrm{~mL})$ and precipitated with diethyl ether $(50 \mathrm{~mL})$ to remove unreacted triazolium salt. The filtrate was reduced and precipitated again with hexane $(50 \mathrm{~mL})$ to remove the unreacted $\mathrm{Pd}(\mathrm{acac})_{2}$, which is soluble in hexane. The yellow precipitate was collected by filtration and washed with hexane. Recrystallization from a mixture of dichloromethane 
and hexane (1:4) gave the complexes as crystalline yellow solids. Single crystals suitable for X-ray diffraction analysis were obtained by slow diffusion of hexane onto a concentrated solution of the complex in dichloromethane.

Palladium(II) complex 1: The product was obtained as yellow solid in a yield of $60 \%(73.1 \mathrm{mg}, 0.12 \mathrm{mmol})$. ${ }^{1} \mathrm{H}-\mathrm{NMR}\left(401 \mathrm{MHz}, \mathrm{CDCl}_{3}, 23{ }^{\circ} \mathrm{C}\right) \delta=7.96-7.91(\mathrm{~m}, 2 \mathrm{H}, \mathrm{Ar}-\mathrm{H}), 7.61-7.50(\mathrm{~m}, 3 \mathrm{H}, \mathrm{Ar}-\mathrm{H}), 7.04-6.98(\mathrm{~m}$, $2 \mathrm{H}, \mathrm{Ar}-\mathrm{H}), 5.14\left(\mathrm{~s}, 1 \mathrm{H}, \mathrm{CH}\right.$ of acac), $4.11\left(\mathrm{~s}, 3 \mathrm{H}, \mathrm{NCH}_{3}\right), 2.37\left(\mathrm{~s}, 3 \mathrm{H}, \mathrm{CH}_{3}\right), 2.29\left(\mathrm{~s}, 3 \mathrm{H}, \mathrm{CH}_{3}\right), 2.16(\mathrm{~s}, 3 \mathrm{H}$, $\left.\mathrm{CH}_{3}\right), 1.85$ (s, 3H, $\mathrm{CH}_{3}$ of acac), $1.76\left(\mathrm{~s}, 3 \mathrm{H}, \mathrm{CH}_{3}\right.$ of acac) ppm. ${ }^{13} \mathrm{C}-\mathrm{NMR}\left(101 \mathrm{MHz}, \mathrm{CDCl}_{3}, 24{ }^{\circ} \mathrm{C}\right)$ $\delta=186.6,183.6$ (CO, acac), 145.6, 141.4, 140.5, 135.6, 135.3, 130.8, 130.1, 129.0, 127.3 (all Aryl-C), 99.1 $(\mathrm{CH}, \mathrm{acac}), 37.8\left(\mathrm{NCH}_{3}\right), 27.6,26.3,21.4$ (all Alkyl-C) ppm. HRMS (ESI): calcd for $\left[\mathrm{C}_{23} \mathrm{H}_{26} \mathrm{IN}_{3} \mathrm{O}_{2} \mathrm{Pd}\right]$ $[\mathrm{M}-\mathrm{I}]^{+} \mathrm{m} / z$ 482.1060, found 482.1065 .

Palladium(II) complex 2: The product was obtained as yellow solid in a yield of $33 \%(43.0 \mathrm{mg}$, $0.066 \mathrm{mmol}) .{ }^{1} \mathrm{H}-\mathrm{NMR}\left(401 \mathrm{MHz}, \mathrm{CDCl}_{3}, 22{ }^{\circ} \mathrm{C}\right) \delta=7.01(\mathrm{~s}, 4 \mathrm{H}$, Aryl- $H), 5.12(\mathrm{~s}, 1 \mathrm{H}, \mathrm{CH}$ of acac), $3.80\left(\mathrm{~s}, 3 \mathrm{H}, \mathrm{NCH}_{3}\right), 2.37\left(\mathrm{p}-\mathrm{d}, 6 \mathrm{H}, \mathrm{CH}_{3}\right), 2.27-2.19\left(\mathrm{~m}, 12 \mathrm{H}, \mathrm{CH}_{3}\right), 1.81\left(\mathrm{~s}, 3 \mathrm{H}, \mathrm{CH}_{3}\right.$ of acac), $1.76(\mathrm{~s}, 3 \mathrm{H}$, $\mathrm{CH}_{3}$ of acac) ppm. ${ }^{13} \mathrm{C}-\mathrm{NMR}\left(126 \mathrm{MHz}, \mathrm{CDCl}_{3}, 21{ }^{\circ} \mathrm{C}\right) \delta=186.4,183.2$ (CO, acac), 151.1 (Carbene-C), 147.8, 144.5, 141.5, 140.5, 140.4, 139.1, 135.6, 135.5, 122.9 (all Aryl-C), $99.0\left(\mathrm{CH}\right.$, acac), $36.5\left(\mathrm{NCH}_{3}\right), 29.8$, 27.6, 26.2, 21.5, 21.4 (all Alkyl-C) ppm. HRMS (ESI): calcd for $\left[\mathrm{C}_{26} \mathrm{H}_{32} \mathrm{IN}_{3} \mathrm{O}_{2} \mathrm{Pd}\right][\mathrm{M}-\mathrm{I}]^{+} \mathrm{m} / \mathrm{z} 524.1529$, found 524.1518 .

Palladium(II) complex 3: The product was obtained as yellow solid in a yield of $45 \%(66.2 \mathrm{mg}, 0.09 \mathrm{mmol})$. ${ }^{1} \mathrm{H}-\mathrm{NMR}\left(400 \mathrm{MHz}, \mathrm{CDCl}_{3}, 20{ }^{\circ} \mathrm{C}\right) \delta=7.53(\mathrm{t}, J=7.8 \mathrm{~Hz}, 2 \mathrm{H}$, Aryl- $H), 7.34(\mathrm{~d}, J=7.8 \mathrm{~Hz}, 4 \mathrm{H}$, Aryl $-H)$, $5.13\left(\mathrm{~s}, 1 \mathrm{H}, \mathrm{CH}\right.$ of acac), $3.78\left(\mathrm{~s}, 3 \mathrm{H}, \mathrm{NCH}_{3}\right), 2.99$ (hept, $\left.J=6.9 \mathrm{~Hz}, 2 \mathrm{H}, \mathrm{CH}\right), 2.92-2.82(\mathrm{~m}, 2 \mathrm{H}, \mathrm{CH}), 1.86$ (s, $3 \mathrm{H}, \mathrm{CH}_{3}$ of acac), 1.81 (s, 3H, CH $\mathrm{CH}_{3}$ acac), $1.36-1.32\left(\mathrm{~m}, 12 \mathrm{H}, \mathrm{CH}_{3}\right), 1.07(\mathrm{dd}, J=10.8,6.9 \mathrm{~Hz}, 12 \mathrm{H}$, $\mathrm{CH}_{3}$ ) ppm. ${ }^{13} \mathrm{C}-\mathrm{NMR}\left(101 \mathrm{MHz}, \mathrm{CDCl}_{3}, 22{ }^{\circ} \mathrm{C}\right) \delta=186.0,183.5$ (CO, acac), 150.2 (Carbene-C), 146.1, 143.5, 143.3, 136.1, 131.5, 131.3, 124.2, 124.2, 123.4 (all Aryl-C), $98.8(\mathrm{CH}, \mathrm{acac}), 37.5\left(\mathrm{NCH}_{3}\right), 30.9,29.1$, 27.7, 27.5, 26.0, 25.1, 24.9, 22.9 (all Alkyl-C) ppm. HRMS (ESI): calcd for $\left[\mathrm{C}_{32} \mathrm{H}_{44} \mathrm{IN}_{3} \mathrm{O}_{2} \mathrm{Pd}\right][\mathrm{M}-\mathrm{I}]^{+} \mathrm{m} / \mathrm{z}$ 608.2468 , found 608.2471 .

\subsubsection{Suzuki-Miyaura Cross Coupling Reactions}

The 4-bromobenzaldeyhde ( $92.5 \mathrm{mg}, 0.5 \mathrm{mmol}, 1 \mathrm{eq}$.), phenylboronic acid (73.2 mg, $0.6 \mathrm{mmol}$, 1.2 eq.) and potassium carbonate $(103.9 \mathrm{mg}, 0.75 \mathrm{mmol}, 1.5$ eq.) were mixed in the presence of water $(1.5 \mathrm{~mL})$ under air. Then complexes 2 or $3(0.5 \mathrm{~mol} \%)$ was added. The mixture was stirred at room temperature for $24 \mathrm{~h}$. For the aryl-chloride, 4-chlorobenzaldeyhde ( $28.1 .5 \mathrm{mg}, 0.2 \mathrm{mmol}, 1 \mathrm{eq}$.), phenylboronic acid ( $20.3 \mathrm{mg}, 0.24 \mathrm{mmol}, 1.2 \mathrm{eq}$.) and cesium carbonate $(130.3 \mathrm{mg}, 0.4 \mathrm{mmol}, 2 \mathrm{eq}$.) were mixed in presence of absolute 1,4-dioxane $(1 \mathrm{~mL})$ under nitrogen atmosphere. After that, complexes 2 or $3(1 \mathrm{~mol} \%)$ was added. The mixture was stirred at $80^{\circ} \mathrm{C}$ for $24 \mathrm{~h}$. The crude reaction mixtures were poured into dichloromethane respectively and extracted with water five times. Finally, the combined aqueous layers were extracted one last time with dichloromethane. The combined organic layers were dried over sodium sulfate, filtered and evaporated to dryness. Afterwards, yields were determined via ${ }^{1} \mathrm{H}-\mathrm{NMR}$ spectroscopy with the help of the aldehyde protons.

\subsubsection{Buchwald-Hartwig Amination}

4-Bromobenzene ( $34.2 \mathrm{mg}, 0.2 \mathrm{mmol}, 1$ eq.), aniline ( $21.9 \mu \mathrm{L}, 22.4 \mathrm{mg}, 0.24 \mathrm{mmol}, 1.2 \mathrm{eq}$.$) , \mathrm{NaOtBu}$ ( $23.1 \mathrm{mg}, 0.24 \mathrm{mmol}, 1.2 \mathrm{eq}$.) and the complexes 2 or $3(4.4 \mathrm{~mol} \%)$ were mixed in the presence of absolute 1,4-dioxane $\left(2 \mathrm{~mL}\right.$ ). The reaction mixture was stirred at $100{ }^{\circ} \mathrm{C}$ for $15 \mathrm{~min}$ in the microwave. The reaction mixture was cooled to room temperature, and the solvent was removed under vacuum. Afterwards, yields were determined via ${ }^{1} \mathrm{H}-\mathrm{NMR}$ spectroscopy with the help of the protons of the methyl-group of the product with 1,3,5-tribromobenzene as internal standard. 


\section{Conclusions}

In conclusion, we have presented here the first examples of three palladium(II) MIC complexes of the type (MIC)Pd(acac)I. Additional to the MIC, the chelating bidentate ligand $\kappa^{2}$-acetylacetonate is coordinated to the palladium(II) center. The synthesis and characterization of all complexes by mass spectrometry, ${ }^{1} \mathrm{H}$ - and ${ }^{13} \mathrm{C}-\mathrm{NMR}$ spectroscopy is described herein. The molecular structure in crystal was verified for two of the three palladium(II) complexes by single crystal X-ray crystallography. Structural characterization revealed the expected square-planar coordination fashion of the palladium(II) center. Due to the popular application of palladium(II) MIC complexes as pre-catalysts in cross coupling reactions, we utilized one of our new complexes as a pre-catalyst in the Suzuki-Miyaura cross coupling reaction. First attempts showed that these kind of complexes are excellent pre-catalysts for the cross coupling of phenylboronic acid with an aryl-bromide as well as an aryl-chloride. The inclusion of the acac ligand on the Pd-MIC unit opens up new possibilities for the synthesis of novel palladium complexes with mesoionic carbene ligands. Changing the donor properties of the acac ligand is conceivable, as is its substitution with other chelating anionic ligands. Such new motifs might open up additional opportunities and perspectives in the chemistry of the metal complexes of MIC ligands.

Supplementary Materials: Supplementary materials can be accessed at: http://www.mdpi.com/1420-3049/21/ $11 / 1561 /$ s1.

Acknowledgments: The Deutsche Forschungsgemeinschaft /DFG) and the Fonds der Chemischen Industrie (FCI) are kindly acknowledged for the financial support of this work. We thank Samir Patra for preliminary work on the Buchwald-Hartwig amination reactions.

Author Contributions: L. Hettmanczyk and B. Sarkar designed the project. Experiments and data analysis was performed by L. Hettmanczyk and B. Schmid. Crystal data were recorded and solved by S. Hohloch. Manuscript was written by L. Hettmanczyk and B. Sarkar.

Conflicts of Interest: The authors declare no conflict of interest.

\section{References}

1. De Frémont, P.; Marion, N.; Nolan, S.P. Carbenes: Synthesis, properties, and organometallic chemistry. Coord. Chem. Rev. 2009, 253, 862-892. [CrossRef]

2. Egbert, J.D.; Cazin, C.S.J.; Nolan, S.P. Copper N-heterocyclic carbene complexes in catalysis. Catal. Sci. Technol. 2013, 3, 912-926. [CrossRef]

3. Kantchev, E.A.; O'Brien, C.J.; Organ, M.G. Palladium complexes of $N$-heterocyclic carbenes as catalysts for cross-coupling reactions-A synthetic chemist's perspective. Angew. Chem. Int. Ed. 2007, 46, 2768-2813. [CrossRef] [PubMed]

4. Loh, C.C.; Enders, D. Merging organocatalysis and gold catalysis-a critical evaluation of the underlying concepts. Eur. J. Chem. 2012, 18, 10212-10225. [CrossRef] [PubMed]

5. Hahn, F.E.; Jahnke, M.C. Heterocyclic carbenes: Synthesis and coordination chemistry. Angew. Chem. Int. Ed. 2008, 47, 3122-3172. [CrossRef] [PubMed]

6. Guisado-Barrios, G.; Bouffard, J.; Donnadieu, B.; Bertrand, G. Crystalline 1H-1,2,3-triazol-5-ylidenes: New stable mesoionic carbenes (MICs). Angew. Chem. Int. Ed. 2010, 49, 4759-4762. [CrossRef] [PubMed]

7. Díez-González, S.; Marion, N.; Nolan, S.P. N-Heterocyclic Carbenes in Late Transition Metal Catalysis. Chem. Rev. 2009, 109, 3612-3676. [CrossRef] [PubMed]

8. Herrmann, W.A. N-heterocyclic carbenes: A new concept in organometallic catalysis. Angew. Chem. Int. Ed. 2002, 41, 1290-1309. [CrossRef]

9. Lalrempuia, R.; McDaniel, N.D.; Müller-Bunz, H.; Bernhard, S.; Albrecht, M. Water oxidation catalyzed by strong carbene-type donor-ligand complexes of iridium. Angew. Chem. Int. Ed. 2010, 49, 9765-9768. [CrossRef] [PubMed]

10. Mercs, L.; Albrecht, M. Beyond catalysis: N-heterocyclic carbene complexes as components for medicinal, luminescent, and functional materials applications. Chem. Soc. Rev. 2010, 39, 1903-1912. [CrossRef] [PubMed] 
11. Sivaram, H.; Tan, J.; Huynh, H.V. Syntheses, characterizations, and a preliminary comparative cytotoxicity study of gold(I) and gold(III) complexes bearing benzimidazole- and pyrazole-derived $N$-heterocyclic carbenes. Organometallics 2012, 31, 5875-5883. [CrossRef]

12. Hickey, J.L.; Ruhayel, R.A.; Barnard, P.J.; Baker, M.V.; Berners-Price, S.J.; Filipovska, A. Mitochondria-targeted chemotherapeutics: The rational design of gold(I) $N$-heterocyclic carbene complexes that are selectively toxic to cancer cells and target protein selenols in preference to thiols. J. Am. Chem. Soc. 2008, 130, 12570-12571. [CrossRef] [PubMed]

13. Maity, R.; Rit, A.; Schulte to Brinke, C.; Daniliuc, C.G.; Hahn, F.E. Metal center dependent coordination modes of a tricarbene ligand. Chem. Commun. 2013, 49, 1011-1013. [CrossRef] [PubMed]

14. Mejuto, C.; Guisado-Barrios, G.; Gusev, D.; Peris, E. First homoleptic MIC and heteroleptic NHC-MIC coordination cages from 1,3,5-triphenylbenzene-bridged tris-MIC and tris-NHC ligands. Chem. Commun. 2015, 51, 13914-13917. [CrossRef] [PubMed]

15. Schmidtendorf, M.; Pape, T.; Hahn, F.E. Stepwise preparation of a molecular square from NR,NR- and NH,O-substituted dicarbene building blocks. Angew. Chem. Int. Ed. 2012, 51, 2195-2198. [CrossRef] [PubMed]

16. Crowley, J.D.; Lee, A.-L.; Kilpin, K.J. 1,3,4-Trisubstituted-1,2,3-triazol-5-ylidene 'click' carbene ligands: Synthesis, catalysis and self- assembly. Aust. J. Chem. 2011, 64, 1118-1132. [CrossRef]

17. Schweinfurth, D.; Deibel, N.; Weisser, F.; Sarkar, B. Mit Klick zu neuen Liganden. Nachr. Chem. 2011, 937-941. [CrossRef]

18. Crabtree, R.H. Abnormal, mesoionic and remote N-heterocyclic carbene complexes. Coord. Chem. Rev. 2013, 257, 755-766. [CrossRef]

19. Donnelly, K.F.; Petronilho, A.; Albrecht, M. Application of 1,2,3-triazolylidenes as versatile NHC-type ligands: Synthesis, properties, and application in catalysis and beyond. Chem. Commun. 2013, 49, 1145-1159. [CrossRef] [PubMed]

20. Aizpurua, J.M.; Fratila, R.M.; Monasterio, Z.; Pérez-Esnaola, N.; Andreieff, E.; Irastorza, A.; Sagartzazu-Aizpurua, M. Triazolium cations: From the "click" pool to multipurpose applications. New J. Chem. 2014, 38, 474-480. [CrossRef]

21. Schulze, B.; Schubert, U.S. Beyond click chemistry-supramolecular interactions of 1,2,3-triazoles. Chem. Soc. Rev. 2014, 43, 2522-2571. [CrossRef] [PubMed]

22. Mathew, P.; Neels, A.; Albrecht, M. 1,2,3-Triazolylidenes as versatile abnormal carbene ligands for late transition metals. J. Am. Chem. Soc. 2008, 130, 13534-13535. [CrossRef] [PubMed]

23. Huisgen, R.; Knorr, R.; Möbius, L.; Szeimies, G. 1.3-Dipolare Cycloadditionen, XXIII. Einige Beobachtungen zur Addition organischer Azide an CC-Dreifachbindungen. Chem. Ber. 1965, 98, 4014-4021. [CrossRef]

24. Huisgen, R.; Szeimies, G.; Möbius, L. 1.3-Dipolare Cycloadditionen, XXXII. Kinetik der Additionen organischer Azide an CC-Mehrfachbindungen. Chem. Ber. 1967, 100, 2494-2507. [CrossRef]

25. Kolb, H.C.; Finn, M.G.; Sharpless, K.B. Click chemistry: Diverse chemical function from a few good reactions. Angew. Chem. Int. Ed. 2001, 40, 2004-2021. [CrossRef]

26. Rostovtsev, V.V.; Green, L.G.; Fokin, V.V.; Sharpless, K.B. A stepwise Huisgen cycloaddition process: Copper(I)-catalyzed regioselective "ligation" of azides and terminal alkynes. Angew. Chem. Int. Ed. 2002, 41, 2596-2599. [CrossRef]

27. Tornøe, C.W.; Christensen, C.; Meldal, M. Peptidotriazoles on solid phase: [1,2,3]-Triazoles by regiospecific copper(I)-catalyzed 1,3-dipolar cycloadditions of terminal alkynes to azides. J. Org. Chem. 2002, 67, 3057-3064. [CrossRef] [PubMed]

28. Kilpin, K.J.; Paul, U.S.; Lee, A.L.; Crowley, J.D. Gold(I) “click” 1,2,3-triazolylidenes: Synthesis, self-assembly and catalysis. Chem. Commun. 2011, 47, 328-330. [CrossRef] [PubMed]

29. Hohloch, S.; Su, C.-Y.; Sarkar, B. Copper(I) complexes of normal and abnormal carbenes and their use as catalysts for the Huisgen [3+2] cycloaddition between azides and alkynes. Eur. J. Inorg. Chem. 2011, 3067-3075. [CrossRef]

30. Hohloch, S.; Sarkar, B.; Nauton, L.; Cisnetti, F.; Gautier, A. Are Cu(I)-mesoionic NHC carbenes associated with nitrogen additives the best $\mathrm{Cu}$-carbene catalysts for the azide-alkyne click reaction in solution? A case study. Tetrahedron Lett. 2013, 54, 1808-1812. [CrossRef] 
31. Hohloch, S.; Scheiffele, D.; Sarkar, B. Activating azides and alkynes for the click reaction with $\left[\mathrm{Cu}(\mathrm{aNHC})_{2} \mathrm{I}\right]$ or $\left[\mathrm{Cu}(\mathrm{aNHC})_{2}\right]+(\mathrm{aNHC}=$ triazole-derived abnormal carbenes $)$ : Structural characterization and catalytic properties. Eur. J. Inorg. Chem. 2013, 3956-3965. [CrossRef]

32. Hohloch, S.; Duecker, F.L.; van der Meer, M.; Sarkar, B. Copper(I) complexes of mesoionic carbene: Structural characterization and catalytic hydrosilylation reactions. Molecules 2015, 20, 7379-7395. [CrossRef] [PubMed]

33. Hohloch, S.; Suntrup, L.; Sarkar, B. Exploring potential cooperative effects in dicopper(I)-di-mesoionic carbene complexes: applications in click catalysis. Inorg. Chem. Front. 2016, 3, 67-77. [CrossRef]

34. Bidal, Y.D.; Lesieur, M.; Melaimi, M.; Nahra, F.; Cordes, D.B.; Athukorala Arachchige, K.S.; Slawin, A.M.Z.; Bertrand, G.; Cazin, C.S.J. Copper(I) complexes bearing carbenes beyond classical $N$-heterocyclic carbenes: Synthesis and catalytic activity in "click chemistry". Adv. Synth. Catal. 2015, 357, 3155-3161. [CrossRef]

35. Canseco-Gonzalez, D.; Petronilho, A.; Müller-Bunz, H.; Ohmatsu, K.; Ooi, T.; Albrecht, M. Carbene transfer from triazolylidene gold complexes as a potent strategy for inducing high catalytic activity. J. Am. Chem. Soc. 2013, 135, 13193-13203. [CrossRef] [PubMed]

36. Wright, J.R.; Young, P.C.; Lucas, N.T.; Lee, A.L.; Crowley, J.D. Gold(I) and palladium(II) complexes of 1,3,4-trisubstituted 1,2,3-triazol-5-ylidene "click" carbenes: Systematic study of the electronic and steric influence on catalytic activity. Organometallics 2013, 32, 7065-7076. [CrossRef] [PubMed]

37. Hettmanczyk, L.; Manck, S.; Hoyer, C.; Hohloch, S.; Sarkar, B. Heterobimetallic complexes with redox-active mesoionic carbenes as metalloligands: Electrochemical properties, electronic structures and catalysis. Chem. Commun. 2015, 51, 10949-10952. [CrossRef] [PubMed]

38. Mendoza-Espinosa, D.; González-Olvera, R.; Negrón-Silva, G.E.; Angeles-Beltrán, D.; Suárez-Castillo, O.R.; Álvarez-Hernández, A.; Santillan, R. Phenoxy-linked mesoionic triazol-5-ylidenes as platforms for multinuclear transition metal complexes. Organometallics 2015, 34, 4529-4542. [CrossRef]

39. Mendoza-Espinosa, D.; González-Olvera, R.; Osornio, C.; Negrón-Silva, G.E.; Santillan, R. Versatile O- and S-functionalized 1,2,3-triazoliums: Ionic liquids for the Baylis-Hillman reaction and ligand precursors for stable MIC-transition metal complexes. New J. Chem. 2015, 39, 1587-1591. [CrossRef]

40. Tolentino, D.R.; Liqun, J.; Melaimi, M.; Bertrand, G. Mesoionic carbene-gold(I) catalyzed bis-hydrohydrazination of alkynes with parent hydrazine. Chem. Asian J. 2015, 10, 2139-2142. [CrossRef] [PubMed]

41. Pretorius, R.; Fructos, M.R.; Müller-Bunz, H.; Gossage, R.A.; Perez, P.J.; Albrecht, M. Synthesis and catalytic applications of 1,2,3-triazolylidene gold(I) complexes in silver-free oxazoline syntheses and C-H bond activation. Dalton Trans. 2016. [CrossRef] [PubMed]

42. Petronilho, A.; Rahman, M.; Woods, J.A.; Al-Sayyed, H.; Müller-Bunz, H.; Don MacElroy, J.M.; Bernhard, S.; Albrecht, M. Photolytic water oxidation catalyzed by a molecular carbene iridium complex. Dalton Trans. 2012, 41, 13074-13080. [CrossRef] [PubMed]

43. Bandaru, S.; English, N.J.; MacElroy, J.M.D. Density functional theory calculations of catalytic mechanistic pathways for the formation of $\mathrm{O}_{2}$ involving triazolylidene iridium complexes. New J. Chem. 2014, 38, 4060-4070. [CrossRef]

44. Petronilho, A.; Woods, J.A.; Bernhard, S.; Albrecht, M. Bimetallic iridium-carbene complexes with mesoionic triazolylidene ligands for water oxidation catalysis. Eur. J. Inorg. Chem. 2014, 2014, 708-714. [CrossRef]

45. Woods, J.A.; Lalrempuia, R.; Petronilho, A.; McDaniel, N.D.; Müller-Bunz, H.; Albrecht, M.; Bernhard, S. Carbene iridium complexes for efficient water oxidation: Scope and mechanistic insights. Energy Environ. Sci. 2014, 7, 2316-2328. [CrossRef]

46. Hohloch, S.; Suntrup, L.; Sarkar, B. Arene-ruthenium(II) and -iridium(III) complexes with "click"-based pyridyl-triazoles, bis-triazoles, and chelating abnormal carbenes: Applications in catalytic transfer hydrogenation of nitrobenzene. Organometallics 2013, 32, 7376-7385. [CrossRef]

47. Hohloch, S.; Hettmanczyk, L.; Sarkar, B. Introducing potential hemilability into "click" triazoles and triazolylidenes: Synthesis and characterization of d6-metal complexes and oxidation catalysis. Eur. J. Inorg. Chem. 2014, 3164-3171. [CrossRef]

48. Maity, R.; Hohloch, S.; Su, C.Y.; van der Meer, M.; Sarkar, B. Cyclometalated mono- and dinuclear Ir(III) complexes with "click"-derived triazoles and mesoionic carbenes. Chem. Eur. J. 2014, 20, 9952-9961. [CrossRef] [PubMed] 
49. Bolje, A.; Hohloch, S.; van der Meer, M.; Kosmrlj, J.; Sarkar, B. Ru(II), Os(II), and Ir(III) complexes with chelating pyridyl-mesoionic carbene ligands: Structural characterization and applications in transfer hydrogenation catalysis. Chem. Eur. J. 2015, 21, 6756-6764. [CrossRef] [PubMed]

50. Bolje, A.; Hohloch, S.; Kosmrlj, J.; Sarkar, B. RuII, IrIII and OsII mesoionic carbene complexes: Efficient catalysts for transfer hydrogenation of selected functionalities. Dalton Trans. 2016. [CrossRef] [PubMed]

51. Hohloch, S.; Kaiser, S.; Dücker, F.L.; Bolje, A.; Maity, R.; Kosmrlj, J.; Sarkar, B. Catalytic oxygenation of sp ${ }^{3}$ "C-H" bonds with Ir(III) complexes of chelating triazoles and mesoionic carbenes. Dalton Trans. 2015, 44, 686-693. [CrossRef] [PubMed]

52. Bernet, L.; Lalrempuia, R.; Ghattas, W.; Müller-Bunz, H.; Vigara, L.; Llobet, A.; Albrecht, M. Tunable single-site ruthenium catalysts for efficient water oxidation. Chem. Commun. 2011, 47, 8058-8060. [CrossRef] [PubMed]

53. Prades, A.; Peris, E.; Albrecht, M. Oxidations and oxidative couplings catalyzed by triazolylidene ruthenium complexes. Organometallics 2011, 30, 1162-1167. [CrossRef]

54. Canseco-Gonzalez, D.; Albrecht, M. Wingtip substituents tailor the catalytic activity of ruthenium triazolylidene complexes in base-free alcohol oxidation. Dalton Trans. 2013, 42, 7424-7432. [CrossRef] [PubMed]

55. Ogata, K.; Inomata, S.; Fukuzawa, S.-I. Position-selective intramolecular aromatic C-H bond activation of 1,2,3-triazol-5-ylidene (tzNHC) ligands in (p-cymene)ruthenium(II) complexes. Dalton Trans. 2013, 42, 2362-2365. [CrossRef] [PubMed]

56. Bagh, B.; McKinty, A.M.; Lough, A.J.; Stephan, D.W. 1,2,3-Triazolylidene ruthenium(II)(eta(6)-arene) complexes: Synthesis, metallation and reactivity. Dalton Trans. 2014, 43, 12807-13146. [CrossRef] [PubMed]

57. Bolje, A.; Hohloch, S.; Urankar, D.; Pevec, A.; Gazvoda, M.; Sarkar, B.; Košmrlj, J. Exploring the scope of pyridyl- and picolyl-functionalized 1,2,3-triazol-5-ylidenes in bidentate coordination to ruthenium(II) cymene chloride complexes. Organometallics 2014, 33, 2588-2598. [CrossRef]

58. Delgado-Rebollo, M.; Canseco-Gonzalez, D.; Hollering, M.; Müller-Bunz, H.; Albrecht, M. Synthesis and catalytic alcohol oxidation and ketone transfer hydrogenation activity of donor-functionalized mesoionic triazolylidene ruthenium(II) complexes. Dalton Trans. 2014, 43, 4462-4473. [CrossRef] [PubMed]

59. Sinn, S.; Schulze, B.; Friebe, C.; Brown, D.G.; Jager, M.; Altuntas, E.; Kubel, J.; Guntner, O.; Berlinguette, C.P.; Dietzek, B.; Schubert, U.S. Physicochemical analysis of ruthenium(II) sensitizers of 1,2,3-triazole-derived mesoionic carbene and cyclometalating ligands. Inorg. Chem. 2014, 53, 2083-2095. [CrossRef] [PubMed]

60. Leigh, V.; Ghattas, W.; Lalrempuia, R.; Müller-Bunz, H.; Pryce, M.T.; Albrecht, M. Synthesis, photo-, and electrochemistry of ruthenium bis(bipyridine) complexes comprising a N-heterocyclic carbene ligand. Inorg. Chem. 2013, 52, 5395-5402. [CrossRef] [PubMed]

61. Sinn, S.; Schulze, B.; Friebe, C.; Brown, D.G.; Jager, M.; Kubel, J.; Dietzek, B.; Berlinguette, C.P.; Schubert, U.S. A heteroleptic bis(tridentate) ruthenium(II) platform featuring an anionic 1,2,3-triazolate-based ligand for application in the dye-sensitized solar cell. Inorg. Chem. 2014, 53, 1637-1645. [CrossRef] [PubMed]

62. Liu, Y.; Kjaer, K.S.; Fredin, L.A.; Chabera, P.; Harlang, T.; Canton, S.E.; Lidin, S.; Zhang, J.; Lomoth, R.; Bergquist, K.E.; et al. A heteroleptic ferrous complex with mesoionic bis(1,2,3-triazol-5-ylidene) ligands: Taming the MLCT excited state of iron(II). Chem. Eur. J. 2015, 21, 3628-3639. [CrossRef] [PubMed]

63. Naziruddin, A.R.; Lee, C.S.; Lin, W.J.; Sun, B.J.; Chao, K.H.; Chang, A.H.; Hwang, W.S. Platinum complexes bearing normal and mesoionic N-heterocyclic carbene based pincer ligands: Syntheses, structures, and photo-functional attributes. Dalton Trans. 2016, 45, 5848-5859. [CrossRef] [PubMed]

64. Soellner, J.; Tenne, M.; Wagenblast, G.; Strassner, T. Phosphorescent platinum(II) complexes with mesoionic 1H-1,2,3-triazolylidene ligands. Chem. Eur.J. 2016, 22, 9914-9918. [CrossRef] [PubMed]

65. Maity, R.; van der Meer, M.; Sarkar, B. Redox-active multinuclear Pd(II) complexes with bis- and tris-mesoionic carbenes. Dalton Trans. 2015, 44, 46-49. [CrossRef] [PubMed]

66. Poulain, A.; Canseco-Gonzalez, D.; Hynes-Roche, R.; Müller-Bunz, H.; Schuster, O.; Stoeckli-Evans, H.; Neels, A.; Albrecht, M. Synthesis and tunability of abnormal 1,2,3-triazolylidene palladium and rhodium complexes. Organometallics 2011, 30, 1021-1029. [CrossRef]

67. Keske, E.C.; Zenkina, O.V.; Wang, R.; Crudden, C.M. Synthesis and structure of palladium 1,2,3-triazol-5-ylidene mesoionic carbene PEPPSI complexes and their catalytic applications in the Mizoroki-Heck reaction. Organometallics 2012, 31, 6215-6221. [CrossRef] 
68. Nakamura, T.; Ogata, K.; Fukuzawa, S.-I. Synthesis of dichlorobis(1,4-dimesityl-1H-1,2,3-triazol-5-ylidene) palladium $\left.\left[\mathrm{PdCl}_{2} \text { (TMes) }\right)_{2}\right]$ and its application to Suzuki-Miyaura coupling reaction. Chem. Lett. 2010, 39, 920-922. [CrossRef]

69. Karthikeyan, T.; Sankararaman, S. Palladium complexes with abnormal N-heterocyclic carbene ligands derived from 1,2,3-triazolium ions and their application in Suzuki coupling. Tetrahedron Lett. 2009, 50, 5834-5837. [CrossRef]

70. Canseco-Gonzalez, D.; Gniewek, A.; Szulmanowicz, M.; Müller-Bunz, H.; Trzeciak, A.M.; Albrecht, M. PEPPSI-type palladium complexes containing basic 1,2,3-triazolylidene ligands and their role in Suzuki-Miyaura catalysis. Chem. Eur. J. 2012, 18, 6055-6062. [CrossRef] [PubMed]

71. Terashima, T.; Inomata, S.; Ogata, K.; Fukuzawa, S.-I. Synthetic, structural, and catalytic studies of well-defined allyl 1,2,3-triazol-5-ylidene (tzNHC) palladium complexes. Eur. J. Inorg. Chem. 2012, 2012, 1387-1393. [CrossRef]

72. Hohloch, S.; Frey, W.; Su, C.Y.; Sarkar, B. Abnormal carbenes derived from the 1,5-cycloaddition product between azides and alkynes: structural characterization of $\mathrm{Pd}(\mathrm{II})$ complexes and their catalytic properties. Dalton Trans. 2013, 42, 11355-11358. [CrossRef] [PubMed]

73. Shaik, J.B.; Ramkumar, V.; Varghese, B.; Sankararaman, S. Synthesis and structure of trans-bis(1,4-dimesityl3-methyl-1,2,3-triazol-5-ylidene)palladium(II) dichloride and diacetate. Suzuki-Miyaura coupling of polybromoarenes with high catalytic turnover efficiencies. Beilstein J. Org. Chem. 2013, 9, 698-704. [CrossRef] [PubMed]

74. Guchhait, S.; Ghosh, K.; Sureshbabu, B.; Ramkumar, V.; Sankararaman, S. C2-Symmetric normal and mesoionic bis- $N$-heterocyclic carbenes with biphenyl backbone. A comparison of bis(1,2,3-triazol-5-ylidene) and bis(imidazol-2-ylidene) ligands. J. Organomet. Chem. 2014, 768, 68-74. [CrossRef]

75. Maity, R.; Mekic, A.; van der Meer, M.; Verma, A.; Sarkar, B. Triply cyclometalated trinuclear iridium(III) and trinuclear palladium(II) complexes with a tri-mesoionic carbene ligand. Chem. Commun. 2015, 51, 15106-15109. [CrossRef] [PubMed]

76. Yuan, D.; Huynh, H.V. Hetero-dicarbene complexes of palladium(II): Syntheses and catalytic activities. Organometallics 2014, 33, 6033-6043. [CrossRef]

77. Mitsui, T.; Sugihara, M.; Tokoro, Y.; Fukuzawa, S.-I. Synthesis of adamantyl substituted 1,2,3-triazol-5-ylidene ligands and their PEPPSI-type palladium complexes. Tetrahedron 2015, 71, 1509-1514. [CrossRef]

78. Modak, S.; Gangwar, M.K.; Nageswar Rao, M.; Madasu, M.; Kalita, A.; Dorcet, V.; Shejale, M.A.; Butcher, R.J.; Ghosh, P. Fluoride-free Hiyama coupling by palladium abnormal N-heterocyclic carbene complexes. Dalton Trans. 2015, 44, 17617-17628. [CrossRef] [PubMed]

79. Mendoza-Espinosa, D.; González-Olvera, R.; Osornio, C.; Negrón-Silva, G.E.; Álvarez-Hernández, A.; Bautista-Hernández, C.I.; Suárez-Castillo, O.R. Structural diversity of phenoxy functionalized triazol-5-ylidene palladium(II) complexes and their application in $\mathrm{C}-\mathrm{N}$ bond formation. J. Organomet. Chem. 2016, 803, 142-149. [CrossRef]

80. Maity, R.; Verma, A.; van der Meer, M.; Hohloch, S.; Sarkar, B. Palladium complexes bearing mesoionic carbene ligands: Applications in $\alpha$-arylation, $\alpha$-methylation and Suzuki-Miyaura coupling reactions. Eur. J. Inorg. Chem. 2016, 111-117. [CrossRef]

81. Mohan, A.; Ramkumar, V.; Sankararaman, S. Synthesis and structures of (-) menthyl and (+) neomenthyl substituted enantio pure bis(1,2,3-triazol-5-ylidene)PdI 2 complexes and PEPPSI type (1,2,3-triazol-5-ylidene) (pyridine) $\mathrm{PdI}_{2}$ complexes. Comparison of catalytic activities for $\mathrm{C}-\mathrm{C}$ coupling. J. Organomet. Chem. 2015, 799-800, 115-121. [CrossRef]

82. Huang, J.; Hong, J.-T.; Hong, S.H. Suzuki-Miyaura cross-coupling reaction catalyzed by PEPPSI-type 1,4-di(2,6-diisopropylphenyl)-1,2,3-triazol-5-ylidene (tzIPr) palladium complex. Eur. J. Org. Chem. 2012, 6630-6635. [CrossRef]

83. Sureshbabu, B.; Ramkumar, V.; Sankararaman, S. A mild and efficient method for the synthesis of structurally diverse 1,2,3-triazolylidene palladium(II) diiodo complexes. Comparison of catalytic activities for Suzuki-Miyaura coupling. J. Organomet. Chem. 2015, 799-800, 232-238. [CrossRef]

84. Navarro, O.; Marion, N.; Scott, N.M.; González, J.; Amoroso, D.; Bell, A.; Nolan, S.P. Synthesis of novel $(\mathrm{NHC}) \mathrm{Pd}(\mathrm{acac}) \mathrm{Cl}$ complexes (acac = acetylacetonate) and their activity in cross-coupling reactions. Tetrahedron 2005, 61, 9716-9722. [CrossRef] 
85. Marion, N.; Ecarnot, E.C.; Navarro, O.; Amoroso, D.; Bell, A.; Nolan, S.P. (IPr)Pd(acac)Cl: An easily synthesized, efficient, and versatile precatalyst for C-N and C-C bond formation. J. Org. Chem. 2006, 71, 3816-3821. [CrossRef] [PubMed]

86. Marion, N.; de Frémont, P.; Puijk, I.M.; Ecarnot, E.C.; Amoroso, D.; Bell, A.; Nolan, S.P. N-heterocyclic carbene-palladium complexes [(NHC)Pd(acac)Cl]: Improved synthesis and catalytic activity in large-scale cross-coupling reactions. Adv. Synth. Catal. 2007, 349, 2380-2384. [CrossRef]

87. Klein, J.E.M.N.; Holzwarth, M.S.; Hohloch, S.; Sarkar, B.; Plietker, B. Redox-active triazolium-derived ligands in nucleophilic Fe-catalysis-reactivity profile and development of a regioselective O-allylation. Eur. J. Org. Chem. 2013, 6310-6316. [CrossRef]

88. Chu, Y.; Deng, H.; Cheng, J.-P. An acidity scale of 1,3-dialkylimidazolium salts in dimethyl sulfoxide solution. J. Org. Chem. 2007, 72, 7790-7793. [CrossRef] [PubMed]

89. Higgins, E.M.; Sherwood, J.A.; Lindsay, A.G.; Armstrong, J.; Massey, R.S.; Alder, R.W.; O’Donoghue, A.C. $\mathrm{pK}_{\mathrm{a}} \mathrm{s}$ of the conjugate acids of $N$-heterocyclic carbenes in water. Chem. Commun. 2011, 47, 1559-1561. [CrossRef] [PubMed]

90. Dröge, T.; Glorius, F. The measure of all rings-N-heterocyclic carbenes. Angew. Chem. Int. Ed. 2010, 49, 6940-6952. [CrossRef] [PubMed]

91. Bouffard, J.; Keitz, B.K.; Tonner, R.; Lavallo, V.; Guisado-Barrios, G.; Frenking, G.; Grubbs, R.H.; Bertrand, G. Synthesis of highly sTable 1,3-diaryl-1H-1,2,3-triazol-5-ylidenes and their applications in ruthenium-catalyzed olefin metathesis. Organometallics 2011, 30, 2617-2627. [CrossRef] [PubMed]

92. Heckenroth, M.; Kluser, E.; Neels, A.; Albrecht, M. Palladation of diimidazolium salts at the C4 position: access to remarkably electron-rich palladium(II) centers. Dalton Trans. 2008, 6242-6249. [CrossRef] [PubMed]

93. Fortman, G.C.; Nolan, S.P. N-Heterocyclic carbene (NHC) ligands and palladium in homogeneous cross-coupling catalysis: A perfect union. Chem. Soc. Rev. 2011, 40, 5151-5169. [CrossRef] [PubMed]

94. Marion, N.; Nolan, S.P. Well-defined N-heterocyclic carbenes-palladium(II) precatalysts for cross-coupling reactions. Acc. Chem. Res. 2008, 41, 1440-1449. [CrossRef] [PubMed]

95. Sheldrick, G.M. SHELXS-97; Program for Crystal Structure Solution and Refinement; University of Göttingen: Göttingen, Germany, 1997.

96. SAINT+. Data Integration Engine, Version 8.276 ${ }^{\odot}$; Bruker AXS Inc.: Madison, WI, USA, 1997-2012.

97. Sheldrick, G.M. A short history of SHELX. Acta Cryst. 2008, 64, 112-122. [CrossRef] [PubMed]

98. Bruker. APEX2; Bruker AXS Inc.: Madison, WI, USA, 2012.

99. Sheldrick, G.M. SHELXL Version 2014/7; Program for crystal structure solution and refinement; University of Göttingen: Göttingen, Germany, 2014.

100. Sheldrick, G.M. Crystal structure refinement with SHELXL. Acta Cryst. 2015, 71, 3-8.

101. Sheldrick, G.M. SADABS, Ver. 2008/1; Program for Empirical Absorption Correction; University of Göttingen: Göttingen, Germany, 2008.

Sample Availability: Samples of the compounds 1-3 are available from the authors.

(C) 2016 by the authors; licensee MDPI, Basel, Switzerland. This article is an open access article distributed under the terms and conditions of the Creative Commons Attribution (CC-BY) license (http://creativecommons.org/licenses/by/4.0/). 